\title{
Author Correction: Partial impairment of insulin receptor expression mimics fasting to prevent diet- induced fatty liver disease
}

\author{
Troy L. Merry, Chris P. Hedges, Stewart W. Masson, Beate Laube, Doris Pöhlmann, Stephan Wueest, \\ Michael E. Walsh, Myrtha Arnold, Wolfgang Langhans, Daniel Konrad (1), Kim Zarse \& Michael Ristow (1)
}

Correction to: Nature Communications https://doi.org/10.1038/s41467-020-15623-z, published online 29 April 2020.

This Article contained an error in Fig. 2i. The alpha-tubulin western blot for the saline-treated samples (left panel) was inadvertently duplicated from the alpha-tubulin western blot for the insulin-treated samples (right panel). This has now been replaced with the correct image. This error has now been corrected in both the PDF and HTML versions of the Article.

Published online: 21 July 2020

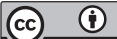

Open Access This article is licensed under a Creative Commons Attribution 4.0 International License, which permits use, sharing, adaptation, distribution and reproduction in any medium or format, as long as you give appropriate credit to the original author(s) and the source, provide a link to the Creative Commons license, and indicate if changes were made. The images or other third party material in this article are included in the article's Creative Commons license, unless indicated otherwise in a credit line to the material. If material is not included in the article's Creative Commons license and your intended use is not permitted by statutory regulation or exceeds the permitted use, you will need to obtain permission directly from the copyright holder. To view a copy of this license, visit http://creativecommons.org/licenses/by/4.0/.

(c) The Author(s) 2020 